Check for updates

New York, USA

Cite this as: BMJ 2020;369:m2403 http://dx.doi.org/10.1136/bmi.m2403 Published: 15 June 2020

\section{Covid-19: Cases still rising in at least 23 US states as health officials warn against gatherings}

\author{
Janice Hopkins Tanne
}

The US should be prepared for a possible rise in cases of covid-19 in coming weeks after thousands of people gathered in protests across the country, warned Tom Inglesby, director of the Johns Hopkins Center for Health Security.

"If we end limits to indoor gatherings, restart conventions, open casinos and restaurants, then I'm worried we may see a resurgence of cases. We know that mass gatherings are where big outbreaks have happened in the US and around the world," he cautioned in a briefing on 11 June.

President Donald Trump plans to hold a rally at an indoor arena holding 19 ooo people on 20 June in Tulsa, Oklahoma. Participants are discouraged from wearing masks but must sign a waiver releasing the auditorium and sponsors from liability if they contract the coronavirus.

In a television interview, Anthony Fauci, director of the National Institute of Allergy and Infectious Diseases, said that people should avoid large gatherings such as protests and political rallies, but if they did attend, they should wear masks. ${ }^{1}$

Covid-19 cases are rising in 23 US states, mostly in the south and west, including California, Texas, and Florida. In some cases, such as California, this may be because of increased testing. In others, such as Texas, it may be because of early reopening. Texas was among the first states to reopen. Nationwide, the rise in cases may result from people getting together over the long weekend at the end of May. However, hospitalisations have increased in Arkansas, North Carolina, Texas, and Utah. There have been more than two million reported cases in the US and more than 115 ooo deaths.

The Centers for Disease Control and Prevention (CDC) continued to stress the need for people to wear face masks and avoid large gatherings where it is difficult to stay six feet apart. It released the results of a survey of 2200 people in New York City and Los Angeles during 5-12 May showing that the public supported restrictions: $79.5 \%$ for stay at home orders and closure of nonessential businesses, $87.7 \%$ for keeping six feet apart, and $82.4 \%$ for no groups larger than 10 . Of those surveyed, $77.3 \%$ said they were self-isolating and $74.3 \%$ said that they would not feel safe if restrictions were lifted. ${ }^{2}$

The CDC also published new guidelines for the public on covid-19 risk, ${ }^{3}$ which labelled as highest risk "large in-person gatherings where it is difficult for individuals to remain spaced at least six feet apart and where attendees travel from outside the local area." Lower risk were smaller gatherings where people could remain spaced at least six feet apart.
At a CDC press briefing on 12 June, Jay Butler, the deputy director for infectious diseases, was asked whether the guidance applied to political rallies. He said, "The guideline is for any type of gathering, whether it's the backyard barbecue or something larger. And it's not intended to endorse any particular type of event. The most important things are being able to maintain social distancing, having access to hand hygiene, encouraging face coverings, and, of course, not attending events if you are ill or have recently been exposed to covid-19."4

\section{Flaherty A. Fauci tells ABC's "Powerhouse Politics" that attending rallies, protests, is "risky." ABC News. 12 June 2020. https://abcnews.go.com/Pol itics/fauci-tells-abcs-powerhouse-politics-attending-rallies-protests/sto- ry?id=71219338 \\ 2 Czeisler MÉ, Tynan MA, Howard ME, et al. Public attitudes, behaviors, and beliefs related to COVID-19, stay-at-home orders, nonessential business closures, and public health guidance: United States, New York City, and Los Angeles, May 5-12, 2020. MMWR Morb Mortal Wkly Rep. 12 June 2020. doi: DOl:10.15585/mmwr.mm6924e1. \\ 3 Centers for Disease Control and Prevention. Considerations for events and gatherings. 12 June 2020. www.cdc.gov/coronavirus/2019-ncov/communi- ty/large-events/considerations-for-events-gatherings.html. \\ 4 Centers for Disease Control and Prevention. Transcript: CDC media telebriefing: update on covid-19. 12 June 2020. www.cdc.gov/media/releas- es/2020/t0612-covid-19-update.html.}

This article is made freely available for use in accordance with BMJ's website terms and conditions for the duration of the covid-19 pandemic or until otherwise determined by BMJ. You may use, download and print the article for any lawful, non-commercial purpose (including text and data mining) provided that all copyright notices and trade marks are retained. 